\title{
Chapter 16 SDG 16: Peace, Justice and Strong Institutions - A Political Ecology Perspective
}

Constance L. McDermott", Emmanuel Acheampong, Seema Arora-Jonsson, Rebecca Asare, Wil de Jong, Mark Hirons, Kaysara Khatun, Mary Menton, Fiona Nunan, Mahesh Poudyal and Abidah Setyowati

\section{Key Points}

- Understanding the impacts of SDG 16 on forests and people requires attention to the power dynamics that shape how all 17 SDGs are interpreted and implemented across the Global North and South.

- As SDGs were agreed upon by nation states, SDG 16 places a strong emphasis on state power and the rule of law.

- Yet inclusive governance requires the involvement of diverse actors, and consideration for customary laws and other non-state forms of rulemaking at global to local scales.

- Many national laws governing forests and land use favour political elite, large-scale industry actors and international trade.

- The development and strengthening of legal frameworks that support all of the SDGs - including those relevant to human rights, income inequalities, land tenure, gender and environmental protection requires equal or greater priority than law enforcement. Otherwise, law enforcement will reinforce inequities and unsustainable practices.

- SDG 16 provides an opportunity to overcome the stereotypes of the Global North as the referential role model for peace and democracy, by highlighting the role of the North in fostering market inequalities and global conflicts, and drawing attention to barriers to democratic and inclusive participation within the Global North.

- How transparency, accountability and justice are conceived and prioritised shapes their impact on forests, as well as the degree to which their achievement either empowers forest-dependent peoples or excludes them from meaningful and informed engagement.

\footnotetext{
* Lead author.
} 


\subsection{Introduction}

SDG 16 highlights core principles of governance relevant to the design and implementation of all 17 SDGs. Yet despite the seemingly universal appeal of principles such as 'peace' and 'justice', negotiations over SDG 16 were heavily contested, revealing a complex geopolitical landscape of competing international priorities (Slotin and Elgin-Cossart 2013). Developing countries have raised concerns that the SDGs might be hi-jacked by the UN's peace and security agenda, perceived as prioritising securitisation while ignoring the links between peace and broader goals such as social equity, climate change mitigation and development (Slotin and Elgin-Cossart 2013). These political battles help to explain the arguably mixed messages embedded in SDG 16's 12 targets (see Table 16.1). While some targets on inclusiveness and justice suggest a pluralist and 'bottom up' approach to governance, many other targets are consistent with Westphalian notions of a strong state ${ }^{1}$ reliant on legal formalisation, and legitimised through representative democracy. The goal's 23 indicators reinforce this emphasis on the state, and are backed by extensive demands for quantitative and qualitative data.

The implications of implementing SDG 16 for forests and forest-dependent peoples depend on how the principles, targets and indicators are interpreted, prioritised, monitored and reported. Implementation may vary, for example, according to whether emphasis is placed on (1) a strong and centralised nation state and the enforcement of state laws and regulations or (2) a more pluralistic or decentralised notion of good governance where power is distributed across scales and institutions, and authority exercised by states, marketbased initiatives and/or ground-up, locally driven processes. Likewise, it will depend on whether states internalise their own visions and commitments to good governance, or whether most of their efforts focus on gathering data and reporting on the 23 more narrowly defined indicators.

The importance of interpretation reflects the socially constructed nature of core governance concepts such as 'justice' and 'accountability', and differing perceptions of the legitimacy and appropriateness of formal versus informal governance, and state-based, market-based and customary institutions. Hence, while the SDGs may represent international consensus on overarching principles of good governance, in practice their implementation will be strongly influenced by the political priorities and power dynamics that continue to unfold at global to local scales. This, in turn, will hold different implications for forests and people in different country contexts.

\footnotetext{
${ }^{1}$ The 1648 treaties of Westphalia were instrumental in enshrining the sovereignty and authority of nation states in international law. See, for example, Cutler 2001: 1024.
} 
Table 16.1 SDG 16 targets

16.1 Significantly reduce all forms of violence and related death rates everywhere

16.2 End abuse, exploitation, trafficking and all forms of violence against and torture of children

16.3 Promote the rule of law at the national and international levels and ensure equal access to justice for all

16.4 By 2030, significantly reduce illicit financial and arms flows, strengthen the recovery and return of stolen assets and combat all forms of organized crime

16.5 Substantially reduce corruption and bribery in all their forms

16.6 Develop effective, accountable and transparent institutions at all levels

16.7 Ensure responsive, inclusive, participatory and representative decisionmaking at all levels

16.8 Broaden and strengthen the participation of developing countries in the institutions of global governance

16.9 By 2030, provide legal identity for all, including birth registration

16.10 Ensure public access to information and protect fundamental freedoms, in accordance with national legislation and international agreements

16.A Strengthen relevant national institutions, including through international cooperation, for building capacity at all levels, in particular in developing countries, to prevent violence and combat terrorism and crime

16.B Promote and enforce non-discriminatory laws and policies for sustainable development

Source: https://sustainabledevelopment.un.org/sdg16

This chapter outlines these complexities and identifies key challenges, opportunities and trade-offs in implementing SDG 16 in a way that is good for forests and people across very different environmental, social and economic contexts. Section 16.2 examines how three inter-related themes articulated in the SDG 16 text intersect with trends in forest governance: (1) peace and the reduction of armed conflict; (2) rule of law, accountability, transparency and access to justice; (3) inclusiveness and participation. These themes are discussed in a general sense, and then case studies illustrate key challenges and trade-offs. Section 16.3 synthesises lessons learned on how context shapes the impacts of SDG 16 implementation, and the implications for promoting 
inclusive and environmentally effective governance. This conclusion speaks to the two 'operationalising targets' of SDG 16 (16A and 16B), focused on institutions and non-discriminatory laws and policies.

Consistent with several other authors in this book, we are less concerned with hypothetical discussions of what it would mean to achieve the ends of universal peace, justice and strong institutions, and more focused on the importance of the means by which states responsible for SDG implementation attempt to achieve these, and how this shapes outcomes. This allows for a more critical, 'political ecology' perspective to unpack how power dynamics shape human-nature interactions and their outcomes. Such an approach recognises the power dynamics inherent in the design and implementation of the SDGs, and the dynamic and contested nature of governance. It highlights how the SDGs are a product of a particular UN process, agreed on by national governments and interpreted and used in the context of international processes, including bi-lateral and multi-lateral finance. This could in part explain the strong implied focus within SDG 16 on state-associated institutions, with much reference to laws, legal enforcement, legal recognition, public officials and other state-centric language. It also sparks broader questions about the relative roles of the Global North and South in deciding how peace and justice are defined and operationalised within the SDGs.

\subsection{Governance under SDG 16}

The term 'governance' has gained increasing traction over the last few decades, reflecting changes in the locus and nature of power and authority under globalisation (Rosenau 1995). Global economic growth and the expansion of international trade have generated new challenges - from deforestation and climate change to social inequalities and civil unrest- that have catalysed new forms of social coordination at multiple scales, involving diverse state, private and civil society actors (Castells 2008, Gunningham 2009).

In this context, 'governance' may be broadly defined as 'the formation and stewardship of the formal and informal rules that regulate the public realm, the arena in which state as well as economic and societal actors interact to make decisions' (Hyden et al. 2004: 16). With specific reference to natural resources, Campese (2016: 7) defines natural resource governance as 'the norms, institutions, and processes that determine how power and responsibilities over natural resources are exercised, how decisions are taken and how citizens - including women, men, youth, Indigenous peoples and local communities - secure access to, participate in, and are impacted by the management of natural resources'. Such an understanding reveals how the governance of 'sustainable development' and associated norms within 
international policy instruments such as the SDGs is not simply a technical challenge involving state actors implementing universally agreed-upon norms; it is an inherently political process involving contestations over who should govern what and for whom (Ferguson 1994).

The globalisation of social and economic relations and the territorial expansion of commercial agriculture and extractive industries, along with associated information technologies and telecommunications, have fostered the expansion of inter-governmental agreements, market-based instruments such as sustainability certification, and multi-stakeholder platforms, all of which interact in complex ways with existing state, local and/or traditional sources of formal and informal authority. The resulting power dynamics are often unequal, with the 'resource-strong' - donors, private entities or governments, often external to the sites of implementation - dictating the terms of trade and creating new governance structures impacting local decision-making. This has spurred conflicts over the appropriate nature and scale of authority, and the relative legitimacy of various institutions to govern decision-making (Bodansky 1999).

The following examination of three themes under SDG 16 will be viewed within this context. In each case we consider the literature on their relation to forests and livelihoods, relevant governance trends, and implications for the implementation of SDG 16 and the SDGs more generally.

\subsubsection{Peace and the Reduction of Violence and Armed Conflict}

SDG 16 covers all forms of violence and abuse, at multiple scales, both organised and un-organised. The strongest emphasis is on physical violence, but psychological violence is also mentioned (Indicator 16.1.3). The literature addressing the impacts of violence on forests and forest-dependent peoples falls into one of two relatively narrow categories: violence against civilians directly related to land and resource conflicts; and indirect impacts on forests and local communities from armed conflicts, such as political rebellion or organised crime.

Most of this literature focuses more on the ends than the means: how conflict does or does not impact forests and people, rather than on how the purpose of the conflict, or how it is suppressed, influences resulting impacts. This is perhaps congruent with a dominant discourse that peace is the natural outcome of the rule of law and democratic participation. Yet, as observed by Paret (2015: 107), the reality is much more complex: 'violent practices may become tools of liberation, promoting democracy by empowering marginalized groups ... [or] ... democracy may become a tool of domination, 
undermining dissent by constituting as violent those persons and actions that deviate from formal institutional channels'.

The realisation of SDG 16 requires that citizens be free to defend their land and resource rights and to engage in environmental advocacy in a nonviolent manner and without fear of intimidation or reprisal. A growing body of evidence suggests this is currently not the case across many regions worldwide. The NGO Global Witness has developed a database of murders of 'environmental defenders': activists or local populations engaged in defending land or natural resources. According to this database, an estimated global average of four environmental defenders are murdered every week (Global Witness 2017). For 2016 and 2017, 16 per cent of these murders were associated with logging and a further 20 per cent with wildlife poaching, often linked to forested areas. These rates are believed to be significantly under-reported, particularly in countries with limited free press, and they exclude much larger numbers of people who are injured, threatened, intimidated or criminalised.

In the broader literature on organised armed conflict, Melander et al. (2016) identify several types: (1) state-based armed conflict, involving at least one government actor; (2) non-state conflicts between rebel groups and militias and (3) one-sided killing of unarmed civilians, by states or formally organised non-state groups. Following World War II, the largest number of deaths are attributed to internal, state-based armed conflict, along with a recent rapid rise in 'internationalised' (internationally supported) intra-state conflict (especially within Syria, where state actors also play a significant role) (Melander et al. 2016). Of significance here, state governments are tasked with SDG implementation when they themselves are sometimes the leading perpetrators of violence. Furthermore, as highlighted by Scott(1998) and Rudel et al. (2009), state actors have historically encouraged the settlement and clearance of forest frontiers as a strategy to solidify their control over rural populations or territories.

Concerning the underlying drivers of armed conflict, Collier and Hoeffler (2000) distinguish between 'grievance', which relates to the acuteness of the professed cause of conflict, and 'greed', denoting the presence of political and economic opportunity. Donovan et al. (2007) and de Koning et al. (2008), looking specifically at forest and conflict linkages, argue for the importance of both grievance and greed in driving conflict and associated forest change. They highlight how people living in or near forests are in many parts of the world at the margins of state support and services. For instance, de Koning (2007) finds that political and economic inequalities were the underlying causes of several of the civil wars that were taking place in West Africa's forests during the first decade of the twenty-first century. Armed conflicts themselves exacerbate causes for grievance because of their negative impact on 
human capital, especially in rural settings - including forest-dependent communities (Chamarbagwala and Morain 2011). However, other contemporary conflict researchers argue that grievance and greed are more correlates of conflict than its drivers, and variously emphasise the causal roles of weak and illegitimate state institutions (e.g. Fearon 2011) or sectarian inequalities (e.g. Stewart 2009).

International actors and large-scale industry also play a role in forest conflict, for example when agricultural and mining firms compete with local communities for land and resources. At the same time, the rise of international governance aimed at forest conservation and reducing forest emissions (themes of SDG 15 and SDG 13, respectively) involves yet another competing set of interests in the forest frontier, focused on carbon, biodiversity and conservation (Fairhead et al. 2012, Kaag and Zoomers 2014, Scheidel and Work 2018).

The international emphasis on conservation has, in some cases, led to 'green militarisation' or the use of military or paramilitary personnel or techniques to protect national parks and limit poaching of wildlife (see Lunstrum 2014). Büscher and Ramutsindela (2015) write of 'green violence', which expands the concept of green militarisation to include broader concepts of violence, both material and non-material, and encompassing discursive and social violence used to promote environmental protection. Green violence includes forced removal of local people from parks, killing of poachers and discourse in favour of such killings (Büscher and Ramutsindela 2015). In some cases, 'shoot-on-sight' policies have been advocated (Messer 2010).

Whatever the causes of violent conflict, its impacts on forests are variable. In terms of biodiversity, the literature reports both negative (Gaynor et al. 2016, Ordway 2015) and positive impacts, the latter largely because the presence of conflict discourages forest access (Álvarez 2003, Burgess et al. 2015, Harwell 2010, McNeely 2003). Forest impacts may increase when the conflict dissipates (Blom and Yamindou 2001) as priority is placed on generating peace dividends, including construction and the resettlement of ex-combatants. Demand for wood and agricultural land may surge during post-conflict years (Harwell 2010). Additionally, negative impacts on forest governance linger, through the limited effectiveness of public administration and poor implementation of forest and nature policies (Staver et al. 2007).

Likewise, conflict has variable effects on forest-dependent communities. Armed conflicts in forest regions often involve interventions by government forces or their allies, which reduces community access to forests, or diminishes the availability of resources (Álvarez 2003, Harwell 2010). Insurgent groups impose demands on communities for food, forest products and other goods and services (Harwell 2010). Under armed conflict conditions, land grabbing is 
more readily condoned, resulting in communities losing access to forests and their goods and services. Displaced groups, especially refugees, turn to forests when other livelihood sources have almost evaporated or livelihoods need to be rebuilt. In such contexts, international sanctions imposed on so-called conflict timber can undermine local economic welfare (Price et al. 2007).

Two reviews on conflict timber (de Jong et al. 2007, Price 2003) synthesise findings across numerous cases of armed conflicts involving forests and forest peoples worldwide, including the two countries we explore in our case studies: Colombia and Peru. Many of these cases are classified as civil wars, although for each the nature of the conflict varied. In all case countries, except perhaps the Democratic Republic of Congo (DRC) and Colombia, the organised armed conflicts have stopped or have transformed into other types of conflict. Many regions remain unstable, characterised by violence, low compliance with state law and ineffective state governments. In Peru and Colombia remnants of insurgence groups continue as organised crime (Pettersson and Wallensteen 2015). In the coming decades, it is possible that organised crime will dominate forest-based armed conflicts, as has happened in Peru and Colombia where Mexican drug cartels have taken over from insurgence groups. This has negative consequences for local people's wellbeing, although not necessarily for their incomes.

These findings highlight how the challenge of reducing violence and armed conflict must be viewed in the broader context of multi-scale governance and environmental and social welfare. A reliance on state actors to quell violence and promote peace could, in some contexts, have negative environmental and social outcomes (UN 2015), including the conversion of forest frontiers to commercial land use as a means to exert state control, and the repression of political dissent (Scott 1998).

\section{CASE STUDY 16.1 PEACEBUILDING IN COLOMBIA AND PERU}

Both Colombia and Peru have undergone extended periods of armed conflict with widespread implications for forest cover and the livelihoods of forestdependent people. In Peru, the Maoist group the Shining Path concentrated their activities in the highlands and the capital city of Lima from the 1980s to the 1990s. The conflicts and instability linked to the violence led to internally displace people (IDPs) (estimates range from 310000 to 600 000), many of whom migrated either to Lima or to forested areas in the Peruvian Amazon. Population growth in the Peruvian Amazon, and subsequent deforestation, is often attributed to this displacement (Ravikumar et al. 2017).

In Colombia, a 2016 peace agreement ended more than 60 years of armed conflict led by the Revolutionary Armed Forces of Colombia (FARC), which concentrated much of its activities in the Amazonian region. As of 2014, there were 5.8 million IDPs in Colombia (Hojen 2015), with some displaced 
as a direct result of the armed conflict, and others due to drug trade and other conflicts.

In both countries, the conflicts were linked to inequality and calls for land reforms. Insecurity of land tenure has been shown to have a negative impact on forest cover in conflict areas in Colombia (Dávalos 2001). Castro-Nuñez et al. (2017a) find further evidence for the importance of unequal land distribution and land grabbing in the conflict, as well as evidence that the presence of forest commons was associated with lower rates of conflict.

Timber may serve as an important means to finance armed conflicts (CastroNuñez et al. 2017a), particularly in forest frontier areas where there is little state presence and a high concentration of commercially valuable species. It is important to note, however, that the presence of forest cover is itself not an indicator of the presence of armed conflict (Harwell 2010, Rustad et al. 2008).

Regarding the net effect of conflict on forests in Colombia and Peru, several main effects have been observed. In both countries, there have been cases of 'gunpoint conservation' where productive activities are curtailed by the violence or enforcement of curfews (Dávalos 2001). There has also been pressure on forest lands due to cultivation of illicit crops (coca) in regions where armed conflicts exclude the presence of law enforcement (Castro-Nuñez et al. 2017a). In Colombia, armed groups actively conserved forest cover as a means to avoid surveillance (McNeely 2003). In Peru, some regions saw displacement to areas with high forest cover in search of safer, more stable living environments (Shanee and Shanee 2016).

Importantly, the impact of armed conflict on forests is not always consistent at national or regional levels. In some cases in Colombia, the FARC used forests as cover for covert operations and/or funded their activities by selling forest resources, thereby maintaining forest cover but contributing to forest degradation (Álvarez 2003). In contrast, in the San Lucas mountain range, the FARC and the National Liberation Army (ELN) actively enforced bans on hunting and logging, thereby protecting some forests from degradation (Dávalos 2001). In cases where the local populations chose to remain, the conflicts significantly impacted land-use and livelihood strategies, thereby influencing forest cover. In other regions, the FARC and the Shining Path encouraged coca cultivation, leading to deforestation (Álvarez 2003). While the FARC were actively promoting coca cultivation, the ELN supported coca eradication and instead promoted mining, which also had negative impacts on forested lands (Dávalos 2001). In areas with gold or lands appropriate for cattle, Sánchez-Cuervo and Aide (2013) find that the presence of armed groups decreased forest cover.

The effect of migration on forests also varies. In the case of Peru, conflict led to migration to cities and to regions of the Amazon with high forest cover. In 
Colombia, where conflict areas were often in regions with high forest cover, migration did not have such a clear impact on forests at the regional scale.

These examples highlight the importance of (1) the particularities of the armed group's activities (e.g. FARC sometimes used forests for cover and other times promoted deforestation for coca cultivation) and (2) the conflict's location relative to areas of high forest cover (e.g. Peru's conflicts in low-forest areas led to migration to forested areas, whereas the reverse is true for Colombia).

While Peru has had almost two decades of peace, Colombia has only recently begun the peacebuilding process. It is important to distinguish between measures that lead to decreases in direct violence (e.g. institutions that limit violence) and those that address the structural drivers of violence (e.g. securing land tenure as a means to address land conflict). Colombia and Peru have gone through different stages in the transition towards lasting peace, and these distinctions are important for the SDGs and links to forests and land-use more broadly. Peacemaking includes processes of negotiation and dialogue to shift away from violent conflict and reach a peace agreement. Peacekeeping usually involves military interventions that help transitions towards peace by separating the fighting parties and actively preventing violence from erupting. Peacebuilding is intended to promote transitions towards lasting peace by addressing the structural causes of conflict and strengthening the capacity of local actors to overcome conflicts (Doyle and Sambanis 2000). Reinstating the 'rule of law' and maintaining it (Peacekeeping and Peacemaking) are not sufficient to address long-held and legitimate grievances (Peacebuilding), nor do they ensure justice (Corntassel and Holder 2008).

Peru's Truth and Reconciliation Commission (CVR) worked in areas affected by the Shining Path to support local communities in their search for peace and reconciliation. A report (CVR 2003) outlining the depth of the conflict, the responsible parties and the long-term impacts recommended reparation actions. Some of these were put into law, but many have not been implemented. The underlying issues of inequality, land conflicts and structural racism towards Indigenous peoples have not been resolved (Corntassel and Holder 2008). This failure's impact on forests remains to be studied.

In Colombia, peacebuilding approaches aim to reduce the causes of conflict (land-related grievances) and to curb access to resources for funding armed groups (e.g. coca). Castro-Nuñez et al. (2017b) found that the current programmes underway in areas emerging from the conflict, including land-tenure programmes, conditional payments for production of alternative crops and forest conservation, are compatible with both development aims 
and forest conservation. Clearly more research will be needed to understand how these programmes unfold in practice.

\subsubsection{The Rule of Law, Accountability, Transparency and Access to Justice}

The rule of law is a major focus of SDG 16, consistent with the wider trend in international governance to promote legality and legal enforcement as pathways to sustainability (McDermott 2014). This trend is particularly evident in the forest sector, having gained major prominence with the rise of illegal logging initiatives in the early 2000s. For example, the EU Forest Law Enforcement, Governance and Trade (FLEGT) Action Plan (EC 2003) has spurred a number of initiatives to eradicate illegal wood from EU supply chains, following the logic that law enforcement is a necessary stepping stone to good governance and sustainability (EC 2003). FLEGT mechanisms include the EU Timber Regulation, which prohibits the import of wood into the EU that was produced in violation of the laws of the country of origin (EC 2010), and Voluntary Partnership Agreements (VPAs) with partner countries in the Global South, for the development of 'legality licensing systems' (EC 2005). Once these systems are in place, all wood imported into the EU from a partner country must bear a special 'legality license' that verifies the wood was legally produced.

This push for legality has spilled into other normative texts and strategies of major relevance to forests. The New York Declaration on Forests, signed by 27 national governments and numerous corporations and NGOs, includes a claim that policies and measures to address illegal logging have 'proven very effective in reducing forest loss' (UN Climate Summit 2014). No evidence is provided to back this statement, but its presence highlights the normative prominence of legality in international discourse. The harnessing of EU markets to demand legal verification is likewise a key recommendation listed in an EU-commissioned feasibility study for an action plan to combat deforestation and degradation, where the scope of legality verification is extended to the production of agricultural crops associated with deforestation (COWI 2018).

SDG 16 couples this emphasis on the rule of law with an approach to accountability and transparency that prioritises the eradication of state-based corruption (Targets $16.5,16.6)$. Specifically, Indicators 16.5 .1 and 16.5 .2 require data quantifying and reporting on levels of individual and corporate bribery of public officials. This aligns, at least in part, with trends in international governance to promote global transparency as a means to facilitate a 'level playing field' for international trade. Such transparency is based on a principle of external 
surveillance and control through standardisation and external monitoring, reporting and verification (e.g. Mutersbaugh 2005, Wood 2013). Applying a universalising discourse of transparency, as a taken-for-granted social good and antidote to corruption, assumes the existence of a functioning state with clear and equitable rules and an even-handed judiciary. This overlooks how complex patron-client relations generally arise in the absence of strong state institutions with widespread legitimacy (Peluso 2018), and how accusations of corruption are frequently harnessed for political gain (Khan 1998).

A universalising, decontextualised conception of transparency is also evident, for example, in the UNFCCC ${ }^{2}$ mechanism Reducing Emissions from Deforestation and Forest Degradation, plus carbon stock enhancement, sustainable forest management, and conservation (REDD+). REDD+ has focused singular attention on the monitoring, reporting and verification (MRV) of forest carbon, a single chemical element amenable to international standardisation and monetisation. The focus on carbon inevitably obscures many other forest values less readily measured and verified by external actors. These other non-carbon environmental and social concerns are subsumed under the REDD+ 'safeguards'.

Sikor (2013) critiques this separation of 'safeguards' from the broader 'technical' design of REDD+, arguing that MRV and other REDD+ technologies of transparency themselves play a central role in shaping the distribution of rights and benefits. Fundamentally, the implementation of REDD+ cannot be separated from the broader governance contexts in which it falls, or from the priorities of those tasked with its enactment on the ground (Khatun et al. 2015, Kull et al. 2015). This intersection of the global and the local has social impacts much less transparent and amenable to international monitoring than changes in forest cover. Decisions about which REDD+ safeguards can and should be monitored are themselves contested. REDD+ poses substantial risks to local communities if it generates new forms of knowledge for national and/or international actors which are poorly understood at local levels, yet may be used to restrict local access to resources.

The interplay of scale and transparency can also be observed in the concept of a 'global commons' inherent in international climate governance. This claiming of space by international actors enables international regulation of practices that previously had local and national provenance. Villagers are thus drawn into a shifting assemblage of international governance, and are subject to new identifications as entrepreneurs and responsible environmental citizens, meant to look after the global commons. While this may be seen, in practice, as 'global citizenship', it involves citizen responsibilities

\footnotetext{
${ }^{2}$ United Nations Framework Convention on Climate Change.
} 
without corresponding rights (Arora-Jonsson et al. 2016). Meanwhile, the growing technical, bureaucratic and political complexity of international processes such as REDD+, and associated MRV, decrease their transparency to most global and local citizens, undermining citizens' abilities to independently assert whatever rights they do hold (McDermott 2014). Hence, incongruously, the transparency called for in initiatives such as REDD+ risks disempowering the people it aims to empower.

International transparency can at times strengthen the power of minority groups, particularly when those minority interests align with broader international norms and agendas. For example, some Indigenous groups have successfully aligned with international environmental or human rights organisations to stop the allocation of mining or other commercial concessions on traditional lands (Woodman 2014). The relevant lesson for SDG 16 is that the effect of international demands for transparency and accountability on forest-dependent peoples depends on what is being made transparent and accountable, and to whom.

The concept of 'justice' articulated in SDG 16 likewise raises questions of justice for what and for whom. Targets 16.3 and 16.9 appear to equate justice with promoting the rule of law and the creation of legal identities through registration (Indicator 16.9.1), while also making select reference to international human rights laws (Indicator 16.8.1). This largely bypasses the difficult question of how state definitions of justice inevitably privilege some actors and some conceptions of justice over others. In contrast, recent literature addressing REDD+ and other payments-for-nature schemes argue that justice, and associated concepts of equity, are better viewed as complex and multidimensional, involving many actors both within and beyond the state, and inevitably requiring trade-offs. For example, McDermott et al. (2013) highlight how equity and justice are socially constructed, and must be understood in the context of how they are defined and by whom, what their goals are and who counts as legitimate subjects of justice or equity. Likewise, they may involve procedural dimensions (e.g. conceptions of due process), as well as distributive (e.g. the fair distribution of benefits) and contextual dimensions. The impact on forests and people of achieving justice under the banner of SDG 16 will similarly depend on the degree to which SDG 16 implementation conceptualises and acknowledges the full assemblage of actors and institutions beyond the state, and whose justice is served or undermined.

The impact of implementing SDG 16 targets that promote the rule of law, transparency and justice will depend on a wide range of factors, including pre-existing formal and informal institutions, and the scales of the actors and markets involved in its implementation. National forest laws in many countries favour political elites and/or large-scale industry actors. The focus 
of international initiatives on international transparency may render local actors, and the impacts on local markets, relatively invisible or illegitimate (Hirons et al. 2018). Yet it is not inevitable that the implementation of SDG 16 will simply reinforce these trends. The following case study in Ghana draws on the examples of FLEGT VPA and REDD+ processes to illustrate how the way governance is understood and approached in any given intervention can further entrench existing power dynamics or lead to transformative change.

\section{CASE STUDY 16.2 A COMPARISON OF THE FLEGT VPA AND REDD+ IN GHANA}

Oil, gold, cocoa, timber and agriculture are the main resources underpinning the Ghanaian economy. For timber and cocoa, in particular, there are concerns over the impact of unsustainable timber harvest and expansion of low-yield cocoa into forested areas. Ghana's timber harvest is three times the annual allowable cut (Hansen et al. 2012) and, coupled with the conversion of forest to cocoa farms, may be undermining the long-term benefits flowing from intact forests, including carbon storage and sequestration and the provision of climatic conditions suitable for cocoa and biodiversity conservation (Benhin and Barbier 2004, Gockowski and Sonwa 2011, Government of Ghana 2005, Hansen et al. 2009, Obiri et al. 2007, Ruf 2011, Wade et al. 2010). Two international policy responses have emerged that align with these concerns: FLEGT's VPA programme and REDD+. ${ }^{3}$ This case study briefly reviews the development of these two strategies in Ghana, comparing key features of their approach to legal reform so as to illustrate differences between strategies that prioritise legal formalisation, auditability and enforcement (top-down) and those that account for customary norms and locally driven governance processes (bottom-up).

It has been estimated that 70 per cent of Ghana's timber production is illegal (Hansen and Treue 2008). In 2009, Ghana and the EU signed a FLEGT VPA trade agreement to eradicate this illegality and stop the import of illegal wood into the EU (Beeko and Arts 2010). The agreement maintains the legal rights of the state over economically valuable timber, which the state may sell to private concessionaires. State control extends to native trees growing on farmlands, so that enforcing state rights effectively marginalises small-scale and local actors. Most farmers have no legal rights to timber growing on their farms, and can only access their timber through illegal harvesting.

At the heart of the VPA strategy is the idea that the legality of timber can be independently verified and audited. To deliver this accountability, the VPA established a Timber Legality Assurance System (TLAS) that includes a wood-tracking system (WTS) to provide an auditable chain of custody for

\footnotetext{
${ }^{3}$ The 'plus' refers to additional objectives associated with enhancing forest carbon stocks, enhancing biodiversity and ensuring the social component of sustainability is addressed.
} 
timber. The TLAS covers imports, pre-felling processes, felling and processing, right through to point-of-sale. Once Ghana's TLAS is accepted by the EU, timber can be sold as 'FLEGT licensed' (i.e. assured legality) and can thereby be imported into the EU. To date, Ghana's efforts to implement the VPA have been focused on producing FLEGT-licensed timber for export, though no FLEGT licenses have been granted in Ghana so far. Well-documented concerns about how the current legal system in Ghana perpetuates the criminality of farmers harvesting trees on their own lands effectively remain unaddressed (Hansen et al. 2018, Hirons 2018).

In a parallel (and largely unconnected) effort, the World Bank has been supporting Ghana's proposals for REDD+ under the UNFCCC to be based on a sustainable intensification strategy for the cocoa sector. This strategy includes a 'climate-smart cocoa' production approach focused on increasing yields (productivity per unit area) through the adoption of best practices and recommended shade levels, combined with community-based landscape governance and land-use planning processes. These measures aim to reduce expansion pressure on forests and to incentivise maintenance and enhancement of carbon stocks in the landscape (Asare 2014). The strategy's success requires that cocoa farmers access critical resources and gain improved tenure. Currently, farmers have little motivation to maintain shade trees because they lack formal rights to native trees $^{4}$ and are therefore incentivised to remove shade trees to minimise the risk that the government will allocate the native trees on their farms to timber concessionaires, who will damage cocoa ${ }^{5}$ when they remove the trees. Although there are legal provisions for farmers to be compensated for damage to their cocoa plants and for community benefits to be provided through Social Responsibility Agreements, these are often ignored, and the majority of benefits are captured by local elites.

In light of these dynamics, the REDD+ process in Ghana prioritises treetenure reform (Asare 2014) that would enshrine the customary norms and rights characterising much of the local decision-making on farms. This would allow farmers to negotiate their own agreements with local authorities concerning the harvest and sale of trees on their farms. ${ }^{6}$ These reforms could be

\footnotetext{
${ }^{4}$ A policy reform in 2002 resulted in the amendment of the Timber Resource Management Act 547 to Act 617. The amended Act 617 makes provision for granting ownership rights to individuals who plant timber trees on farmlands. However, these rights do not apply to naturally regenerating trees, and if farmers plant native trees it is difficult for them to prove that they were planted and not naturally recurring.

${ }_{5}$ Timber contractors use heavy machinery to drag whole trees out of farms, damaging cocoa trees in the process. Chainsaw operators 'slice' the trees where they are felled and the lumber is carried out by hand, which is considerably less damaging to cocoa.

${ }^{6}$ Government revenues under a reformed tenure system would be provided for by taxation in markets, rather than stumpage fees, which are not collected by the state when felling is illegal.
} 
tested and refined under existing proposals, such as the community resource management area (CREMA) mechanism, which authorises communities to manage their own resources. Monitoring would be largely based on indicators reflecting the CREMA development and management process; CREMA would report on outcomes to partner entities. This locally tailored approach contrasts with standardised international systems that focus on external monitoring and control. The CREMA approach potentially delivers greater rights to communities in managing the resources they steward and greater proportions of the associated benefits.

These two major forest policy initiatives in Ghana have contrasting approaches to governance and legal reform. The FLEGT VPA focuses on state control over forest resources and emphasises auditability and enforcement while the tree-tenure reforms under REDD+ propose to incorporate customary norms into statutory law. These two approaches have markedly different impacts on local groups. Under FLEGT, the local domestic producers and consumers of timber risk further criminalisation and exclusion from the benefits of timber harvest as a livelihood activity (Hansen et al. 2018, Hirons et al. 2018). Under REDD+, proposals for tree tenure improve local actors' ability to control and benefit from trees on their land (Asare 2014).

This characterisation of the difference between FLEGT and REDD+ in Ghana is somewhat simplified. ${ }^{7}$ The findings also cannot, by themselves, be generalised to other country contexts. The intent here is to illustrate how the assumed links between legality and sustainability should be more critically and deeply investigated. Forest laws can be legal yet ecologically unsustainable and socially inequitable; illegal production can be both sustainable and fair. Approaches to legal reform that attempt to incorporate the informal rules and norms underpinning sustainable resource management are more likely to support the wider objectives outlined in the SDGs than those that benefit large private entities and states at the cost of marginalising and criminalising local actors.

\subsubsection{Inclusiveness and Participation}

Target 16.7 calls for 'responsive, inclusive, participatory and representative decision-making at all levels'. Like the previous themes, the indicators under this target strongly imply a focus on state institutions and nationallevel reporting. Trends in international discourse on governance encompass a much broader and more far-reaching understanding of participation. For the forest sector this means a push towards decentralisation in forest governance

\footnotetext{
7 For example, tree-tenure reform has also been mooted during FLEGT discussions, but it is REDD+ that is leading the way on current efforts on this issue.
} 
across levels of government, as well as the active involvement of non-state actors and local communities in decision-making (Arts 2014, Gilmour 2016).

In many parts of the world more participatory approaches to forest management have been formalised through community-based or collaborative forest management. It is estimated that in 62 countries, covering 65 per cent of the world's forests, 28 per cent of the forest area is community managed (Gilmour 2016). Under such arrangements, forest users are often required to set up a decision-making structure, usually based on elected community representation, such as a forest-user group or committee, with a mandate and functions prescribed in legislation. In practice, these initiatives are mostly 'top-down', unlike some customary and Indigenous governance systems which in some cases are rooted in centuries of traditional practice. While state-regulated arrangements provide opportunities for forest users to participate in forest management in ways that are recognised and supported by the state, the governance structures and systems may either conflict with existing customary practice or reinforce inequities, thereby falling short of fully inclusive or representative decision-making. It is often the case within communities that elites - those with higher status, power and/or wealth - dominate formal community management and co-management systems at the local level, steering decisions and capturing benefits.

Given sufficient time and investment, state-orchestrated participation can offer opportunity for non-elites to challenge this elite capture. For example, Lund and Saito-Jensen (2013), in their study of participatory forestry in Tanzania and India over more than a decade, observe that over time marginalised people successfully organised themselves and formed alliances with external actors to resist elite control, and made use of electoral systems to gain increased authority. Likewise, Persha and Andersson (2014) find that the involvement of external agencies, such as NGOs, can help to reduce the scale and negative effects of elite capture.

Research on the opportunities for women to be part of participatory forest structures and processes has, for example, examined which factors enable and constrain women's participation and whether women's presence has any impact on the nature and effectiveness of forest management. Agarwal (2009, 2010) finds that women's participation in community forest institutions in India and Nepal often led to stricter rules, though other factors can also be at play. Coleman and Mwangi (2013) find that women from households with higher levels of education and wealth are more likely to be influential participants in community forestry. Arora-Jonsson (2014) argues that the mandatory presence of women in forest committees may simply rubber-stamp legitimacy to external actors without changing the status quo. Women have gained greater influence over decision-making by organising women's groups 
outside of mainstream institutions. Arora-Jonsson advocates for acknowledging the multiple spaces in which everyday decision-making on the forests actually takes place, including informal types of social organisation (e.g. informal village groups tasked with keeping forests and villages clean, fetching water, planting herbs in the forest) that are frequently overlooked by external actors and researchers (Arora-Jonsson 2009).

Regarding the overall impacts of formal participatory forest processes, there is some evidence of positive outcomes for forest cover (Bowler et al. 2012, Gilmour 2016), but inadequate evidence of improved livelihoods (Samii et al. 2015). Bowler et al. (2012) call for capacity for evaluation to be built into participatory forest management programmes. An FAO review of 40 years of community-based forestry ${ }^{8}$ identifies the following as key challenges for sustainable forest management: (1) the adoption of such approaches tends to be found in highly degraded forests that offer little in the way of benefits to communities; (2) communities are often not granted access to valuable resources, particularly timber; (3) the emphasis is on protection rather than management; and (4) decision-making power largely remains with the central government (Gilmour 2016). This reflects what has happened with decentralisation more generally, where the majority of decision-making power and resources remain with central government. These patterns continue, despite widespread recognition of the need for participation to be meaningful, inclusive and equitable (Nunan et al. 2018). Additionally, studies of participatory forest management tend to focus on cases where external actors are involved in conceptualising, implementing or supporting community forest activities. A myriad of traditional, community-based management strategies are often not included in these reviews or impact studies.

The meaningful inclusion of local communities in resource management depends on the strength of their underlying land tenure and use rights, and their capacity to benefit from those rights (Ribot and Peluso 2003). Multicountry synthesis studies of research on community forestry reiterate the importance of the bundles of rights communities have to land and resources, including the material benefit from forests (Baynes et al. 2015, Gnych et al. 2018). These overarching issues of rights and access are notably absent from SDG 16 targets and indicators.

The following case studies serve to situate these challenges to participatory forest management in specific country contexts. Case Study 16.3 illustrates Indonesia's high levels of ambition and investment in community forestry,

\footnotetext{
${ }^{8}$ The literature varies on the definitions and terms used to refer to participatory approaches to forest management. Our focus here is deliberately broad, and encompasses a range of practices which include community-based forestry, participatory forest management and other associated frames.
} 
as well as the many challenges and trade-offs faced in realising that ambition. Case Study 16.4 provides a comparative case study of Sweden and India that challenges commonly held assumptions about the relative quality of participation in the Global North and South.

\section{CASE STUDY 16.3 INCLUSION AND EXCLUSION IN INDONESIA'S SOCIAL FORESTRY INITIATIVE}

Around 91 per cent of Indonesia's forested areas are administered by the state, and communities in an estimated 31957 villages in and around forest areas lack secure access to forests and livelihoods (RRI 2013). In recognition of this, the government of Indonesia has recently spearheaded a major push towards social forestry, with an ambitious target to allocate 12.7 million ha of forest area to local and Indigenous communities by 2019 , as stipulated by a series of social forestry policies. ${ }^{9}$ These policies have the triple objectives of securing communities' access to forest resources, alleviating poverty and improving forest conditions. This landmark decision has been praised by many as a promising pathway for more inclusive and equitable development. It is also hoped it will clarify forest tenure, and resolve widespread and longstanding forest tenure conflicts (Eghenterr et al. 2017).

A core procedural mechanism for Indonesia's social forestry strategy has been to engage a diversity of stakeholders in social forestry working groups at the national and provincial levels. These groups currently cover 24 out of 34 provinces and engage 1118 individuals as focal points (Social Forestry Working Group 2017). The working groups are intended to facilitate the development and implementation of social forestry policies and stimulate the achievement of social forestry targets through preparing and updating digital maps to determine targeted priority areas, ${ }^{10}$ as well as to carry out capacity-building activities and support communities with permit applications and permit verification processes. To speed up the achievement of the social forestry target, in 2016 the government issued an integrated social forestry policy that is expected to simplify procedures to obtain a permit, thereby reducing the time it takes from up to several years to a maximum of three months.

\footnotetext{
${ }^{9}$ Under social forestry policies, communities will be able to apply permits to manage the 'state forests' through several schemes: (a) community forestry (hutan kemasyarakatan); (b) village forests (hutan desa); (c) community plantation forests (hutan tanaman rakyat); (d) customary forests (hutan adat) and (e) forming partnership with private sectors (kemitraan kehutanan). Unlike other social forestry schemes, which only provide communities with rights to access forest resources, adat forest allows communities to have ownership rights over their customary forests. This was made possible by a constitutional court ruling that stipulates adat forests should no longer be considered part of state forests.

${ }^{10}$ Peta Persiapan Perhutanan Sosial or a preparation map for social forestry target.
} 
Nevertheless, progress in reaching targets has been slow relative to ambitions, with a total of 1065056 ha reported as designated in September 2017 (MoEF 2017). The recognition of customary (adat) forests has been slower still (Myers et al. 2017). Out of the 9.1 million ha identified as adat forest in a map prepared by the National Indigenous People's Alliance of the Archipelago (AMAN), only 17092 ha have been recognised by the state (Arumingtyas 2018). This slow progress is due, in part, to long and arduous government procedures, and overlapping claims over forestlands (Arumingtyas 2018, HUMA 2015).

While Indonesia's social forestry policies emphasise seemingly inclusionary politics, their implementation shows various forms of exclusion that could limit Indigenous and local communities' ability to benefit from forest resources. Despite inclusive processes at the national and provincial levels, Indigenous and local communities are at risk of being minimally involved at the village level due to the rush to achieved targeted hectares allocated for social forestry schemes. Field observations of social forestry policy implementation in several sites in Central Kalimantan suggest that local and Indigenous communities are minimally engaged in the issuance of social forestry permits. In the haste to issue permits to meet ambitious targets, and given the complexity of the permitting process, many members of communities holding such permits lack awareness of the rights and responsibilities the permits entail. ${ }^{11}$ Some community members consider the permits additional burdens if the forestlands allocated to them are neither productive nor easily accessible. There is also evidence of elite capture (Maryudi et al. 2012), and/ or the exclusion of women from forest decision-making processes and forest benefits (Setyowati 2012). Other forest-user groups remain excluded from the process entirely, including transmigrant communities, or communities making claims to lands allocated to company concessions or conservation areas, or to lands that have been removed from the category of state forestlands (Myers et al. 2017).

With the exception of adat forests, forest tenure reform in the social forestry policies refers to allocating usufruct rights to communities while retaining the state's ownership over the forestlands. Most of the legal rights stipulated in the forestry policies are time bound and come with use restrictions based on the classification of the allocated forest (Moeliono et al. 2017). For instance, a social forestry permit stipulated in a protected forest (hutan lindung) requires communities to improve forest protection and only allows the use of non-timber forest products. Moreover, the allocation is conditional

\footnotetext{
${ }^{11}$ Informal discussion with villagers on the community forest plantation permit (HTR), Pulang Pisau District, Central Kalimantan, November 2016.
} 
on fulfilling responsibilities that communities often find difficult, such as submitting management plans and managing the forest in accordance with particular technical requirements. In a recent social forestry scheme which specifically targeted forest areas in Java, controlled by the state-owned enterprise, only severely degraded forest areas in need of rehabilitation could be allocated to communities. ${ }^{12}$ Without sufficient technical and budgetary support, such allocations, rather than improving local development, limit local economic aspirations and further marginalise local communities.

\section{CASE STUDY 16.4 THE INTERNAL AND EXTERNAL POLITICS OF PARTICIPATION IN} SWEDEN

Seema Arora-Jonsson's work (2018) challenges the discourse of international development that paints the Global North as a referent for democracy and public participation, and the Global South as in need of Northern assistance and capacity-building to achieve conformity with Northern ideals. She illustrates this argument through case studies of Sweden as both a domestic and an international actor, contrasting Sweden's domestic and international policies regarding democratic decision-making in environmental governance (2018).

She points to the 1990 s as an era that institutionalised international norms of decentralisation, embedded, in part, in a neoliberal agenda to shift environmental responsibility to local groups and individuals (Arora-Jonsson 2017). Within this trend, Sweden played a leading role in highlighting the importance of people's participation in decision-making, as well as serving as an international champion for gender equality. Gender forms a central theme and a priority for the Swedish Development Agency (Sida) and Sida was instrumental in supporting the World Bank to make participation of different groups central to questions of development aid. This contrasts with the relative absence of the mention of people's participation in environmental policy-making within Sweden, including few requirements for government workers to employ a gender perspective.

Her comparative case studies of two forest communities, in India and Sweden, likewise illustrate the disconnect between Sweden's international image as a gender champion and its local realities in forestry decision-making. In the Nayagarh district in Odisha, India, the openly acknowledged gender differences voiced by local actors, with support from NGOs and international actors, legitimised the formation of women's groups and collective action to address women's priorities. In contrast, in the village of Drevdagen in western Sweden, cultural perceptions of Sweden as a highly developed, modern

${ }^{12}$ MoEF Decree No.39/2017 on Social Forestry Schemes in Perum Perhutani Area. 
country with strong norms of gender equality served to diminish the collective voice of women. In such a context, complaints of female oppression could be written off as signs of the weakness of individual women who have failed to assert themselves socially, or as an aberration in a country assumed to be gender-equal, rather than a reflection of broader societal discrimination (Arora-Jonsson 2009).

\subsection{Conclusion}

Understanding SDG 16 from a political ecology perspective requires attention to how states and other actors exercise their power in interpreting and implementing the SDGs. These dynamics are influenced by a range of larger governance trends, as well as by complex local particularities. States form the core authority behind the SDGs and are responsible for reporting on indicators, which at least partially explains why the language of SDG 16 places such a strong emphasis on state institutions. However, an understanding of governance as multi-nodal, networked and contested makes it impossible to ignore how reinforcing state power may undermine other governance institutions, such as traditional and local authorities.

In order to examine these issues, this chapter focuses on three different thematic areas encapsulated in SDG 16 - peace, justice and participation - to identify what existing literature can tell us about how SDG 16 implementation might impact forests and people. These analyses have also been grounded in more specific case studies to further unpack associated opportunities and challenges.

In regards to peace, our findings illustrate how peace cannot be separated from the broader context of environmental and social welfare. While SDG 16 emphasises the state's role as enforcer of the peace, an over-reliance on state actors to quell violence and promote peace can, in some contexts, have negative environmental and social outcomes, including the assertion of state control through the conversion of forests into commercial agriculture and/ or repression of political dissent. The literature reveals varying effects of armed conflict on forest cover, resulting in either a net gain or loss of cover. This variation is observed both within and between countries, as witnessed in Case Study 16.1 on Colombia and Peru. Post-conflict periods are often associated with forest loss, through state-sponsored settlement schemes and other forms of securitisation of frontier areas, as well as the expansion of agricultural land and resource extraction fuelled by economic recovery and growth.

Regarding the second SDG theme - the rule of law, accountability, transparency, and access to justice - the impacts on forests and people of realising 
these goals will depend on a wide range of contextual factors, including preexisting formal and informal institutions, and the scales of the actors and markets involved. National laws governing forests and land use in many countries favour political elite and/or large-scale industry actors, as do government policies encouraging commercial expansion into forest frontiers. Law enforcement without legal and policy reforms to dis-incentivise land conversion and to improve local resource rights and benefit capture could drive forest loss and the displacement of local communities. Furthermore, the focus of international initiatives on international transparency may legitimise large producers and industries based on their ability to control and track their supply chains, while rendering local actors, local markets and local livelihoods illegitimate or invisible (Scott 1998). This could further disempower rural communities and undermine their access to natural resources, while contributing to increased urban and international commodity consumption. Nevertheless, in some cases local actors may leverage international attention to successfully defend their interests against the state, particularly if their cause is aligned with international norms and agendas.

It is not inevitable that the implementation of SDG 16 will reinforce existing inequities. As illustrated by Case Study 16.2 of the FLEGT VPA and REDD+ in Ghana, the way in which governance is understood and approached in any given intervention can either further entrench existing power dynamics or lead to more transformative change. Approaches to legal reform which recognise the informal rules and norms underpinning sustainable resource management are more likely to support the wider SDG objectives than approaches that reinforce state laws designed to benefit large private entities and states.

Our analysis of the third theme - inclusiveness and participation - highlights the prevalence of the concept in international discourse and the diversity of ways in which it has been operationalised in the forest sector. These include the legal recognition of some form of community control over increasing areas of the world's forests. As highlighted in the Indonesian case, participation is time-consuming, costly and contentious. It can become more burdensome than empowering if it is accompanied by increasing accountability demands from states and other actors, and if these demands are not balanced with adequate benefits. Ambitious targets dictated at national or international levels to hand over forests to communities can overwhelm capacities for meaningful implementation.

The Swedish case unpacks the stereotypes of the Global North as the referential role model of democracy and participation for the Global South. Assumptions about Sweden as a developed country that has solved participation issues through formal legal means preclude attention to questions of 
participation and gender in resource decision-making on the ground. By contrasting Swedish policies at home and abroad, Arora-Jonsson $(2009,2018)$ deconstructs the development divide - the modern state in the Global North versus the not-quite modern state in the Global South - and how this might be used to further particular interests in either place. All the SDGs aim to motivate countries to self-assess and improve their efforts to reach common goals; this may open up the space for debating these important transnational relationships.

SDG 16 reflects international agreement on the importance of participatory processes and local decision-making. In the context of forests, this means recognising that forest use, management and governance can fail some people, and that long-term solutions to social and environmental problems, while global in scope, may result in local injustices. Furthermore, current research indicates that the heavily state-centric focus of the SDG 16 targets and indicators as a means to achieve good governance risks reinforcing these injustices. This suggests that SDG 16 may best be served through greater acknowledgement of non-state actors and institutions at multiple scales - from traditional governance systems to global-scale initiatives - and adjusting the appropriate mix of governance approaches to individual national, sub-national and local contexts. This also argues against a heavy focus on the standardised, quantitative metrics associated with SDG 16's reporting requirements. Instead, what is needed are placed-based assessments of the power dynamics of particular governance systems, and the identification of actions to address inequities in ways that are locally and contextually appropriate.

While the achievement of a truly inclusive and sustainable development, with justice for all and at all levels, is a laudable goal, it must not obscure the inevitable trade-offs inherent in governance, and, indeed, in the very concept of equity. It is critical to keep a power-informed perspective in the implementation of SDG 16 that acknowledges these trade-offs and leaves room for healthy conflicts and struggles among state and non-state actors alike. Creating adequate space for conflict and dispute is integral to the pursuit of individual and social welfare, peace and fulfilment.

\section{References}

Agarwal, B. 2009. Rule making in community forestry institutions: The difference women make. Ecological Economics 68:2296-308.

Agarwal, B. 2010. Gender and green governance: The political economy of women's presence within and beyond community forestry. Oxford: Oxford University Press.

Álvarez, M. 2003. Forests in the time of violence: Conservation implications of the Colombian War. Journal of Sustainable Forestry 16(3-4):47-68. 
Arora-Jonsson, S. 2009. Discordant connections: Discourses on gender and grassroots activism in two forest communities in India and Sweden. Signs: Journal of Women in Culture and Society 35(1):1-28.

Arora-Jonsson, S. 2014. Forty years of gender research and environmental policy: Where do we stand? Women's Studies International Forum 47:295-308.

Arora-Jonsson, S. 2017. Blind spots in environmental policy-making: How beliefs about science and development may jeopardize environmental solutions. World Development Perspectives 5:27-29.

Arora-Jonsson, S. 2018. Across the development divide: A North-South perspective on environmental democracy. In Marsden, T. (ed.) Sage handbook of Nature. Sage Publications, pp. 1-24.

Arora-Jonsson, S. Westholm, L., Petitt, A. and Temu B. J. 2016. Carbon and cash in climate assemblages: The making of a new global citizenship. Antipode 48(1):74-96.

Arts, B. 2014. Assessing forest governance from a 'Triple G' perspective: Government, governance, governmentality. Forest Policy and Economics 49:17-22.

Arumingtyas, L. 2018. Pengakuan Hutan Adat Minim: Perlu Terobosan Baru di 2018. Mongabay (8 January). Available at: www.mongabay.co.id/ (Accessed 15 January 2018).

Asare, R. A. 2014. Understanding and defining climate-smart cocoa: Extension, inputs, yields, and farming practices. Accra, Ghana: Climate-Smart Cocoa Working Group, Nature Conservation Research Centre and Forest Trends.

Baynes, J., Herbohn, J., Smith, C., Fisher, R. and Bray, D. 2015. Key factors which influence the success of community forestry in developing countries. Global Environmental Change 35:226-38.

Beeko, C. and Arts, B. 2010. The EU-Ghana VPA: A comprehensive policy analysis of its design. International Forestry Review 12(3):221-30.

Benhin, J. K. and Barbier, E. B. 2004. Structural adjustment programme, deforestation and biodiversity loss in Ghana. Environmental and Resource Economics 27(3):337-66.

Blom, A. and Yamindou, J. 2001. A brief history of armed conflict and its impact on biodiversity in the Central African Republic. Washington, DC: Biodiversity Support Program, USAID/WWF.

Bodansky, D. 1999. The legitimacy of international governance: A coming challenge for international environmental law? American Journal of International Law 93(3):596-624.

Bowler, D. E., Buyung-Ali, L. M., Healey, J. R., et al. 2012. Does community forest management provide global environmental benefits and improve local welfare? Frontiers in Ecology and the Environment 10(1):29-36.

Burgess, R., Miguel, E. and Stanton, C. 2015. War and deforestation in Sierra Leone. Environmental Research Letters. doi:10:095014.

Büscher, B. and Ramutsindela, M. 2015. Green Violence: Rhino poaching and the war to save Southern Africa's Peace Parks. African Affairs 115:1-22.

Campese, J. 2016. Natural resource governance framework assessment guide: Learning for improved natural resource governance. IUCN/CEESP NRGF Working Paper, Gland, Switzerland: IUCN and CEESP. 
Castells, M. 2008. The new public sphere: Global civil society, communication networks, and global governance. The Annals of the American Academy of Political and Social Science 616(1):78-93. doi:10.1177/0002716207311877.

Castro-Nuñez, A., Mertz, O., Buritica, A., Sosa, C. C. and Lee, S. T. 2017a. Land related grievances shape tropical forest-cover in areas affected by armed conflict. Applied Geography 85:39-50.

Castro-Nuñez, A., Mertz, O. and Sosa, C. C. 2017b. Geographic overlaps between priority areas for forest carbon-storage efforts and those for delivering peacebuilding programs: implications for policy design. Environmental Research Letters 12(5):054014.

Chamarbagwala, R. and Morán, H. E. 2011. The human capital consequences of civil war: Evidence from Guatemala. Journal of Development Economics 94(1):41-61.

Coleman, E. A. and Mwangi, E. 2013. Women's participation in forest management: A crosscountry analysis. Global Environmental Change 23:193-205.

Collier, P. and Hoeffler A. 2002. Greed and grievance in Civil War. The World Bank Policy Research Working Paper 2355. Washington, DC: World Bank.

Corntassel, J. and Holder, C. 2008. Who's sorry now? Government apologies, truth commissions and Indigenous self-determination in Canada, Australia, Guatemala and Peru. Human Rights Review 9(4):1.

COWI 2018. Feasibility study on options to step up EU action against deforestation. EU, ECOFYS, Milieu, COWI.

Cutler, A. C. 2001. Critical reflections on the Westphalian assumptions of international law and organization: a crisis of legitimacy. Review of International Studies 27:133-150.

CVR (Comissión de la Verdad y Reconciliación) 2003. Peru Truth and Reconciliation Commission Final Report. Lima, Peru. Available at: www.cverdad.org.pe/ingles/ifinal/index.php (Accessed 20 February 2019).

Dávalos, L. M. 2001. The San Lucas mountain range in Colombia: How much conservation is owed to the violence? Biodiversity \& Conservation 10(1):69-78.

de Jong, W., Donovan, D. and Ken Ichi, A. (eds.) 2007. Tropical forests and extreme conflicts.

Dordrecht: Springer.

de Koning, R. 2007. Greed or grievance in West Africa's forest wars? In de Jong, W., Donovan, D. and Abe, K. (eds.) Extreme conflicts and tropical forests. Dordrecht: Springer, pp. 37-56.

de Koning, R., Capistrano, D, Yasmi, Y. and Cerutti, P. 2008. Forest-related conflict: Impact, links, and measures to mitigate. Washington, DC: Rights and Resources Initiative.

Donovan, D., de Jong, W. and Abe, K. 2007. Tropical forest and extreme conflict. In de Jong, W., Donovan, D. and Abe, K. (eds.) Extreme conflicts and tropical forests. Dordrecht: Springer, pp. 1-15.

Doyle, M. W. and Sambanis, N. 2000. International peacebuilding: A theoretical and quantitative analysis. American Political Science Review 94(4):779-801.

EC 2003. Forest Law Enforcement, Governance and Trade (FLEGT) Proposal for an EU Action Plan. European Commission. 
EC 2005. Council Regulation (EC) No 2173/2005 on the establishment of a FLEGT licensing scheme for imports of timber into the European Community. European Commission.

EC 2010. Regulation (EU) No 995/2010 of the European Parliament and of the Council of 20 October 2010 laying down the obligations of operators who place timber and timber products on the marketText with EEA relevance. European Commission.

Ece, M., Murombedzi, J. and Ribot, J. 2017. Disempowering democracy: Local representation in community and carbon forestry in Africa. Conservation and Society 15(4):357-70.

Eghenterr, C., Suhardjito, D., Purwanto, E. et al. 2017. Mewujudkan Hak Rakyat: Reformasi Penguasaan Tanah dan Pengelolaan Hutan. Proceedings of Academic Papers for Tenure Conference 2017, Jakarta.

Fairhead, J., Leach, M. and Scoones, I. 2012. Green grabbing: A new appropriation of nature? The Journal of Peasant Studies 39(2):237-61.

Fearon, J. D. 2011. Governance and civil war onset. Washington, DC: World Bank. Available at: https://openknowledge.worldbank.org/handle/10986/9123 (Accessed 29 July 2019). License: CC BY 3.0 IGO.

Ferguson, J. 1994. The anti-politics machine: Development, depoliticization and bureaucratic power in Lesotho. The Ecologist 24:176-81.

Gaynor, K. M., Fiorella, K. J., Gregory, G. H. et al. 2016. War and wildlife: Linking armed conflict to conservation. Frontiers of Ecological Environments 14(10):533-42.

Gilmour, D. 2016. Forty years of community-based forestry. A review of its extent and effectiveness. FAO Forestry Paper 176. Rome: FAO.

Global Witness 2018. At what cost? Irresponsible business and the murder of land and environmental defenders in 2017. London.

Gnych, S., Lawry, S., Monterroso, I. and Adhikary, A. 2018. Common benefits: Is community tenure facilitating investment in the commons for inclusive and sustainable development? Paper presented at the World Bank Conference on Land and Property, Washington, DC, 4 March.

Gockowski, J. and Sonwa, D. 2011. Cocoa intensification scenarios and their predicted impact on $\mathrm{CO}_{2}$ emissions, biodiversity conservation, and rural livelihoods in the Guinea rain forest of West Africa. Environmental Management 48(2):307-21.

Government of Ghana 2005. Growth and Poverty Reduction Strategy (2006-2009). Republic of Ghana, Accra.

Gunningham, N. 2009. Environment law, regulation and governance: Shifting architectures. Journal of Environmental Law 21(2):179-212.

Hansen, C. P., Damnyag, L., Obiri, B. D. and Carlsen K. 2012. Revisiting illegal logging and the size of the domestic timber market: The case of Ghana. International Forestry Review 14(1):39-49.

Hansen, C. P., Lund. J. F. and Treue, T. 2009. Neither fast, nor easy: The prospect of Reduced Emissions from Deforestation and Degradation (REDD) in Ghana. International Forestry Review 11 (4):439-55.

Hansen, C. P., Rutt, R. and Acheampong, E. 2018. 'Experimental' or business as usual? Implementing the European Union Forest Law Enforcement, Governance and Trade (FLEGT) Voluntary Partnership Agreement in Ghana. Forest Policy and Economics 96:75-82. 
Hansen, C. P. and Treue, T. 2008. Assessing illegal logging in Ghana. International Forestry Review $10(4): 573-90$.

Harwell, E. 2010. Forests in fragile and conflict-affected states. Washington, DC: Program on Forests (PROFOR).

Hirons, M., McDermott, C., Asare, R. et al. 2018. Illegality and inequity in Ghana's cocoa-forest landscape: How formalization can undermine farmers' control and benefits from trees on their farms. Land Use Policy 76:405-413. doi:1.1016/j.landusepol.2018.02.014.

Hojen, L. 2015. Colombia's 'invisible crisis': Internally displaced persons. Council on Hemispheric Affairs. Available at: www.coha.org/colombias-invisible-crisis-internally-displaced-persons/ (Accessed 20 February 2019).

HUMA (Association for Law Reform Based on Community and Ecology) 2015. Penetapan Hutan Adat Menuju Pengakuan Hak Masyarakat Adat. Jakarta: HUMA.

Hyden, G., Court, J. and Mease, K. 2004. Making sense of governance: Empirical evidence from sixteen developing countries. London: Lynne Reiner.

Kaag, M. and Zoomers, A. 2014. The global land grab: Beyond the hype. Chicago: Zed Books.

Khan, M. H. 1998. The role of civil society and patron-client networks in the analysis of corruption. In Corruption and integrity improvement initiatives in developing countries. New York: UNDP, Management Development and Governance Division, pp. 111-28.

Khatun, K., Gross-Camp, N., Corbera, E., Martin, A., Ball S. and Massao, G. 2015. When participatory forest management makes money: Insights from Tanzania on governance, benefit sharing, and implications for REDD+. Environmental and Planning A 47:2097-112. doi:10.1177/0308518X15595899.

Kull, C. A., Arnauld de Sartre, X. and Castro-Larrañaga, M. 2015. The political ecology of ecosystem services. Geoforum 61:122-34.

Lund, J. F. and Saito-Jensen, M. 2013. Revisiting the issue of elite capture of participatory initiatives. World Development 46:104-12.

Lunstrum, E. 2014. Green militarization: Anti-poaching efforts and the spatial contours of Kruger National Park. Annals of the Association of American Geographers 104(4):816-32.

Maryudi, A., Devkota, R. R., Schusser, C. et al. 2012. Back to basics: Considerations in evaluating the outcomes of community forestry. Forest Policy and Economics 14(1):1-5.

McDermott, C. L. 2014. REDDuced: From sustainability to legality to units of carbon - the search for common interests in international forest governance. Environmental Science and Policy 35:12-19, doi:10.1016/j.envsci.2012.08.012.

McDermott, M., Mahanty, S. and Schreckenberg, K. 2013. Examining equity: A multidimensional framework for assessing equity in payments for ecosystem services. Environmental Science and Policy 33:416-27. doi:10.1016/j.envsci.2012.10.006.

McNeely, J. A. 2003. Biodiversity, war, and tropical forests. Journal of Sustainable Forestry 16(3-4):1-20.

Melander, E., Pettersson, T. and Themnér, L. 2016. Organized violence, 1989-2015. Journal of Peace Research 53(5):727-42. doi:10.1177/0022343316663032.

Messer, K. D. 2010. Protecting endangered species: When are shoot-on-sight policies the only viable option to stop poaching? Ecological Economics 69:2334-2340. 
MoEF (Ministry of Environment and Forestry) 2017. Capaian percepatan perhutanan sosial 2017. MoEF presentation at the tenure conference in Jakarta, Indonesia, October 2017.

Moeliono, M., Thuy, P. T. and Wong, G. Y. 2017. A comparison of policies in Vietnam and Indonesia. Forest Policy and Society 1(2):1-20.

Mutersbaugh, T. 2005. Fighting standards with standards: Harmonization, rents, and social accountability in certified agrofood networks. Environment and Planning A 37(11):2033-51. doi:10.1068/A37369.

Myers, R., Intarini, D., Sirait, M. T. and Maryudi, A. 2017. Claiming the forest: Inclusions and exclusions under Indonesia's 'new' forest policy on customary forest. Land Use Policy 66:205-17.

Nunan, F., Menton, M., McDermott, C. and Schreckenberg, K. 2018. Governing for ecosystem health and human wellbeing. In Schreckenberg, K., Mace, G. and Poudyal, M. (eds.) Ecosystem services for poverty alleviation: Trade-offs and governance. London: Routledge, pp. 159-73.

Obiri, B. D., Bright, G. A., McDonald, M. A., Anglaaere, L. and Cobbina, J. 2007. Financial analysis of shaded cocoa in Ghana. Agroforestry Systems 71(2):139-49.

OECD 2015. OECD Public Governance Review. Indonesia Highlights. Available at: www.oecd.org/ gov/open-gov-review-indonesia.pdf (Accessed 12 January 2018).

Ordway, E. M. 2015. Political shifts and changing forests: Effects of armed conflict on forest conservation in Rwanda. Global Ecology and Conservation 3:448-60.

Paret, M. 2015. Violence and democracy in South Africa's community protests. Review of African Political Economy 42(143):107-23. doi:10.1080/03056244.2014.995163.

Peluso, D. 2018. Traversing the margins of corruption amidst informal economies in Amazonia. Culture, Theory and Critique 59:400-18.

Persha, L. and Andersson, K. 2014. Elite capture risk and mitigation in decentralized forest governance regimes. Global Environmental Change 24:265-76.

Pettersson, T. and Wallensteen, P. 2015. Armed conflicts, 1946-2014. Journal of Peace Research 52(4):536-50.

Price, S. V. 2003. War and tropical forests: Conservation in areas of armed conflict. Journal of Sustainable Forestry Special Issue 16:3-4.

Price, S., Donovan, D. and de Jong, W. 2007. Confronting conflict timber. In de Jong, W., Donovan, D., and Abe, K. (eds.) Extreme conflicts and tropical forests. Dordrecht, Netherlands: Springer, pp. 117-32.

Ravikumar, A., Sears, R. R., Cronkleton, P., Menton, M. and Pérez-Ojeda del Arco, M. 2017. Is small-scale agriculture really the main driver of deforestation in the Peruvian Amazon? Moving beyond the prevailing narrative. Conservation Letters 10(2):170-77.

Ribot, J. C., Lund, J. F. and Treue, T. 2010. Democratic decentralization in sub-Saharan Africa: Its contribution to forest management, livelihoods, and enfranchisement. Environmental Conservation 37(1):35-44.

Ribot, J. C. and Peluso, N. L. 2003. A theory of access. Rural Sociology 68:153-81.

Rosenau, J. N. 1995. Governance in the twenty-first century. Global Governance 1(1):13-43. 
RRI (Rights and Resources Institute) 2013. Tenure data and tools. Available at: https:// rightsandresources.org/ (Accessed 22 January 2018).

Rudel, T., DeFries, R., Asner, G. P. and Laurance, W. 2009. Changing drivers of deforestation and new opportunities for conservation. Conservation Biology 23(6):1396-1405.

Ruf, F. O. 2011. The myth of complex cocoa agroforests: The case of Ghana. Human Ecology 39(3):373-88.

Rustad, S., Rød, J. K., Larsen, W. and Gleditsch, N. P. 2008. Foliage and fighting: Forest resources and the onset, duration, and location of civil war. Political Geography (27):761-82.

Samii, C., Lisiecki, M., Kulkarni, P., Paler, L. and Chavis, L. 2015. Decentralised forest management for reducing deforestation and poverty in low- and middle- income countries: A systematic review. Systematic Review 16. London: International Initiative for Impact Evaluation (3ie).

Sánchez-Cuervo, A. M. and Aide, T. M. 2013. Consequences of the armed conflict, forced human displacement, and land abandonment on forest cover change in Colombia: A multiscaled analysis. Ecosystems 160:1052-70.

Scheidel, A. and Work, C. 2018. Forest plantations and climate change discourses: New powers of 'green' grabbing in Cambodia. Land Use Policy 77:9-18.

Scott, J. C. 1998. Seeing like a state: How certain schemes to improve the human condition have failed. Yale Agrarian Studies. New Haven: Yale University Press.

Setyowati, A. 2012. Ensuring that women benefit from REDD+. Unasylva 239(63):57-62.

Shanee, N. and Shanee, S. 2016. Land trafficking, migration, and conservation in the 'no-man's land' of northeastern Peru. Tropical Conservation Science 9(4):1-16. doi: 1940082916682957.

Sikor, T. 2013. REDD+: Justice effects of technical design. In The justices and injustices of ecosystem services. London: Routledge, pp. 47-68.

Slotin, J. and Elgin-Cossart, M. 2013. Why would peace be controversial at the United Nations? Negotiations toward a post-2015 development framework. New York University. New York: Center on International Cooperation.

Social Forestry Working Group 2017. Strategi Percepatan Implementasi Perhutanan Sosiial, Terobosan dalam Mengelola Tantangan dan Hambatannya. Paper presentation at Tenure Conference, October 2017.

Staver, C., de Jong, W., Kaimowitz, D. 2007. Nicaragua's frontier: The Bosawas Biosphere Reserve. In de Jong, W., Donovan, D. and Abe, K. (eds.) Extreme conflicts and tropical forests. Dordrecht: Springer., pp. 51-74.

Stewart, F. 2009. Horizontal inequalities as a cause of conflict. Bradford Development Lecture: November 2009. Available at: www.academia.edu/28567760/Horizontal_inequalities_as_a_ cause_of_conflict (Accessed 27 July 2019).

Transparency International. 2016. Corruption perception index 2016. Available at: www .transparency.org (Accessed 15 January 2018).

UN 2015. The challenge of sustaining peace: Report of the advisory group of experts for the 2015 review of the United Nations peacebuilding architecture. New York: United Nations. 
McDermott, Acheampong, Arora-Jonsson et al.

UN Climate Summit 2014. New York Declaration on Forests Declaration and Action Agenda. New York: United Nations.

Wade, A. S. I., Asase, A., Hadley, P. et al. 2010. Management strategies for maximizing carbon storage and tree species diversity in cocoa-growing landscapes. Agriculture, Ecosystems \& Environment 138(3-4):324-34.

Wood, D. M. 2013. What is global surveillance? Towards a relational political economy of the global surveillant assemblage. Geoforum 49:317-26.

Woodman, J. 2014. India's rejection of Vedanta's bauxite mine is a victory for tribal rights. The Guardian. 14 January. Available at: www.theguardian.com/global-development/povertymatters/2014/jan/14/india-rejection-vedanta-mine-victory-tribal-rights (Accessed 20 February 2019). 